Вісник Дніпропетровського університету. Серія: геологія, географія. 24 (2), 2016, 18-24.

Vìsnik Dnìpropetrovs'kogo unìversitetu. Serîa Geologîa, geographìâ

Dnipropetrovsk University Bulletin. Series: geology, geography. 24 (2), 2016, 18-24.

Doi: $10.15421 / 111627$

http://geology-dnu.dp.ua

УДК 550.42

\title{
Закономірності розподілу важких металів в об'сктах навколишнього середовища м. Суми
}

\author{
Ю. Ю. Войтюк ${ }^{1}$ І. В. Кураєва ${ }^{1}$, Г. А. Кроїк ${ }^{2}$, О. В. Мацібора ${ }^{3}$ О. В. Матвієнко ${ }^{1}$ \\ ${ }^{1}$ Інститут геохімії, мінералогії та рудоутворення імені М.П. Семененка НАН України, Київ, Украӥна, е-таіl: \\ yuliasun86@mail.ru \\ ${ }_{2}^{2}$ Дніпропетровський національний університет імені Олеся Гончара, Дніпро, Украӥна \\ ${ }^{3}$ Інститут географї̈ НАН Украӥни, Київ, Украӥна
}

Наведено результати еколого-геохімічних досліджень грунтів, рослинного покриву та природних вод урбанізованої території м. Суми. Мета цієї роботи - визначення закономірностей розподілу важких металів в об'сктах довкілля. За середнім значенням сумарного показника забруднення встановлено, що рівень забруднення грунтів центральної частини міста нижчий середнього. Вони характеризуються такою асоціацією важких металів: $\mathrm{Pb}(3,4)>\mathrm{Cr}(2,9)>\mathrm{Cu}$ $(2,2)>\mathrm{Ni}(2,1)>$ Со $(1,8)$. Ірунти зони впливу основного корпусу ТОВ «Сумитеплоенерго» характеризуються середнім (помірно небезпечним), а грунти поблизу золошлаконакопичувача - високим (небезпечним) рівнем забруднення. Встановлено техногенні геохімічні асоціації важких металів, досліджено основні джерела забруднення, що спричинюють накопичення токсикантів у компонентах міського середовища. На техногенно забруднених ділянках (територія ТОВ «Сумитеплоенерго») вмісти важких металів у золі пирію повзучого (Elytrigia repens (L.) Nevski) вдвічі-втричі більші порівняно із фоновою ділянкою. В поверхневих водах р. Псел зони впливу ТОВ «Сумитеплоенерго» значно підвищується вміст таких важких металів відносно фонових значень: Cu, Zn, Mn, Ni, Cr, V. Встановлено, що відбувся процес метаморфізації перших від поверхні водоносних горизонтів у зоні впливу золошлаконакопичувача ТОВ «Сумитеплоенерго». Визначення закономірностей розподілу важких металів у грунтах, рослинності та природних водах дозволяє виділити аномальні поля та зробити прогноз екологічних ризиків.

Ключові слова: важкі метали, трунти, рослинність, природні води

\section{Peculiarities of the heavy metals distribution in the different objects of Sumy city environment}

\author{
Iu. Iu.Voitiuk' ${ }^{1}$ I. V. Kuraeva ${ }^{1}$, A. A. Kroik ${ }^{2}$, O. V. Matsibora $^{3}$, A. V. Matvienko ${ }^{1}$ \\ ${ }^{1}$ M.P. Semenenko Institute of Geochemistry, Mineralogy and Ore Formation, National Academy of Sciences of Ukraine, \\ Kyiv, Ukraine, e-mail: yuliasun86@mail.ru \\ ${ }_{2}^{2}$ Dnipropetrovsk National University Oles Honchar, Dnepropetrovsk, Ukraine \\ ${ }^{3}$ Institute of Geography of the National Academy of Sciences of Ukraine, Kyiv, Ukraine
}

Results of the ecological and geochemical investigation of soils, vegetation and water resources of Sumy city environment are considered in this paper. The aim of scientific investigation is definition of the main peculiarities of heavy metals distribution in some environmental objects (soils, vegetation and water resources) of Sumy city. Special attention was payed to investigation of regularities of heavy metals distribution in "Sumyteploenergo Ltd." affected area. Concentration of chemical elements in samples was determined by classical geochemical and modern methods on mass spectrometer with inductively coupled plasma (ICP-MS) in the M.P. Semenenko Institute of geochemistry, mineralogy and ore formation of the National Academy of sciences of Ukraine. Based on an analysis of the total indicator of pollution were defined that the level of soil's pollution in the central part of the city is lower then average values. They have following association $-\mathrm{Pb}(3,4)>\mathrm{Cr}(2,9)>\mathrm{Cu}(2,2)>\mathrm{Ni}(2,1)>\mathrm{Co}$ $(1,8)$. Soils in the "Sumyteploenergo Ltd." main building affected area are characterized by middle (moderately hazardous) level of pollution, but soils near slurry tanks have high (hazardous) level of pollution with heavy metals. Also the technogenic geochemical associations of heavy metals were defined, and the main sources of pollution, which determine toxic elements accumulation in the components of environment, were investigated. Activity of "Sumyteploenergo Ltd." during many years led to changes in natural distribution of heavy metals in all investigated objects of environment. In technogenically polluted areas (territory of "Sumyteploenergo Ltd.") the concentration of heavy metals in ash of Elytrigia repens (L.) Nevski increases significantly compared with the natural values. In surface water of Psel river in "Sumyteploenergo Ltd." affected area the content of $\mathrm{Cu}, \mathrm{Zn}, \mathrm{Mn}, \mathrm{Ni}, \mathrm{Cr}, \mathrm{V}$ is much higher then in outside water objects. This investigation proves that the processes of metamorphism of the surface waters horizons in the affected area of "Sumyteploenergo Ltd." slurry tanks took place. Analysis of tailings showed that they are characterized by high concentration of many chemical elements, especially high values are typical for $\mathrm{V}, \mathrm{Cr}, \mathrm{Cu}, \mathrm{Pb}$ and $\mathrm{Zn}$. As the result of geochemical investigations were defined that high concentration of these 
elements are specific for soils and surface water in the affected area of "Sumyteploenergo Ltd". Conclusions and their analysis of this investigation give the main representation of peculiarities of heavy metals pollution in different industrial areas of urban territory. In the study area some industrial zones were defined, which are characterized by special chemical elements pollution and peculiarities of their distribution. Investigation of environmental objects showed the strong relations between specializing of industrial production and defined geochemical associations of chemical elements and their distribution. This important not only for determination the main sources of heavy metals, but for environmental protection activities. Investigation of heavy metals distribution peculiarities in soils, vegetation and surface waters gives abilities for determination anomalous fields and making prognosis of ecological risks.

Keywords: heavy metals, soils, vegetation, water resources

Вступ. Важлива риса розвитку людства на сучасному етапі - це пришвидшення процесу урбанізації. Постійно зростають площі міських агломерацій. Збільшення кількості міського населення зумовлює формування нових способів взаємодії у системі людина - навколишнє середовище. Урбанізація має глобальний характер і виступає фактором суттєвої трансформації геологічного середовища, в результаті чого розвиваються специфічні утворення - урбоекосистеми. Підвищення значення міста у житті людства зумовлює концентрацію ресурсів та їх споживачів на відносно невеликих ділянках простору, що спричинує виникнення диспропорцій у балансі використання та відновлення природного середовища.

Наразі проблеми урбогеохімії все більше починають цікавити науковців (Flight, Scheib, 2011; Kabata-Pendias, Pendias, 2001; Kuimova, Sergeeva, Shumilova, Pavlova, Borisova, 2012; Wong, Sharp, Hauwert, Landrum, White, 2012). Особлива увага приділяється містам, де концентруються промислові підприємства (Karmazynenko, Kurajeva, Samchuk, Vojtjuk, Manichev, 2014; Saet, Revich, Janin, 1990; Samchuk, Ogar', 2008).

Серед населених пунктів Сумської області найбільшого антропогенного навантаження зазнає атмосфера м. Суми - 10,93 тис. т. або 36,17 \% від викидів стаціонарних джерел по області (“Dopovid' pro stan”, 2013), що не може не відзначатися на стані об'єктів довкілля та якості життя міського населення в цілому.

Також одна з основних проблем міста щодо охорони атмосферного повітря - це питання морально та фізично застаріле технологічне обладнання промислових підприємств. За останні роки майже на всіх підприємствах міста установки очищення газу, технологічне обладнання не оновлювались (кількість обладнання 3 терміном експлуатації 40 років і більше складає понад $70 \%$ ). На промислових підприємствах міста протягом останніх років майже не впроваджувались найкращі доступні, екологічно чисті технології (“Dopovid' pro stan", 2013).
За даними Сумського обласного центру з гідрометеорології, загальний рівень забруднення атмосферного повітря в останні роки деякими шкідливими речовинами в м. Суми стабілізувався, але залишається підвищеним. Спостереження за вмістом пилу, діоксиду сірки, оксиду вуглецю, діоксиду та оксиду азоту, аміаку, формальдегіду проводились щоденно на трьох стаціонарних постах. Середньомісячні концентрації пилу та діоксиду азоту в атмосферному повітрі перевищували санітарні норми в 1,2 - 1,3 раза. Інші інгредієнти, що визначались, нижчі або на рівні санітарних норм. Перевищень максимально разових гранично допустимих концентрацій $з$ жодної домішки не зафіксовано. Високих та екстремально високих рівнів забруднення атмосферного повітря у м. Суми протягом останніх років не спостерігалось (“Dopovid' pro stan", 2013).

Найбільше підприємство енергетичної галузі Сумської області - ТОВ «Сумитеплоенерго» (4 648,9 т викидів або 15,4 \% від викидів по Сумській обл.). У процесі використання як палива вугілля на підприємстві утворюються золошлаки, які видаляються у спеціально побудованому золошлаконакопичувачі. Це місце видалення відходів експлуатується з 1968 р. і на сьогодні вже практично заповнене (“Dopovid' pro stan”, 2013).

Існує нерозривний взаємозв'язок та взаємозалежність між умовами теплоенергоспоживання та забрудненням навколишнього середовища. В умовах постійного зростання теплоенергоспоживання сучасним суспільством проблема взаємодії теплоенергетики і навколишнього середовища стає все гострішою і потребує постійного контролю, наукового аналізу з метою зменшення негативного впливу на компоненти середовища та оцінки екологічних ризиків.

Мета роботи - визначення закономірностей розподілу важких металів в об'єктах довкілля (грунтах, рослинності, поверхневих та підземних водах) м. Суми.

Матеріал і методи досліджень. Для проведення еколого-геохімічних досліджень було обрано 
ділянки: центральна частина м. Суми; основний корпус ТОВ «Сумитеплоенерго» (правий берег р. Псел); золошлаконакопичувач ТОВ «Сумитеплоенерго» (лівий берег р. Псел); фонова ділянка (в 10 км у напрямку рози вітрів). Відібрано зразки грунтів, рослинності, поверхневих вод р. Псел та підземних вод у зоні впливу ТОВ «Сумитеплоенерго» і на фоновій ділянці. На ділянці золошлаконакопичувача додатково відібрано зразки техногенного матеріалу (зола і шлами). Відбір проб грунту проведено відповідно до вимог ГОСТ 17.4.4.02-84 3 верхнього гумусового горизонту $0-10$ см. Опробування представницьких видів рослинності проведено паралельно з відбором грунтових проб.

Концентрації хімічних елементів у пробах визначалися методами атомно-емісійного спектрального аналізу на СТЕ-1 спектрографі великої дисперсії і мас-спектрометрії з індукційно-зв'язаною плазмою (ICP-MS) (Ponomarenko, Samchuk, Krasjuk, Makarenko, Antonenko, 2008) в Інституті геохімії, мінералогії та рудоутворення імені М. П. Семененка НАН України. Еколого-геохімічну оцінку за сумарним показником забруднення дано за методикою Ю. Ю. Саєта (Saet et al., 1990). Результати та їх аналіз. Найбільш інформативні ореоли розсіювання техногенних елементів у грунтових відкладах, що виражають надходження і накопичення хімічних елементів за значний період часу. Тому особливу увагу було приділено еколого-геохімічним дослідженням грунтового покриву.
Грунти м. Суми представлені переважно чорноземами типовими мало- і слабогумусовими на лесових породах, чорноземами опідзоленими переважно на лесових породах, луговими солонцюватими на делювіальних і алювіальних відкладах, які зазнали значного техногенного забруднення.

Проведено дослідження валового вмісту важких металів у грунтах центральної частини м. Суми, зон впливу ТОВ «Сумитеплоенерго» та фонових значень (табл. 1).

Як показали наші дослідження та розрахунок коефіцієнтів концентрації, грунти центральної частини м. Суми характеризуються такою асоціацією важких металів: $\mathrm{Pb}(3,4)>\mathrm{Cr}(2,9)>\mathrm{Cu}(2,2)>\mathrm{Ni}(2,1)>\mathrm{Co}$ $(1,8)$. За середнім значенням сумарного показника забруднення (СПЗ) встановлено, що рівень забруднення цих грунтів нижчий середнього (СПЗ - 9).

Щодо ділянок зони впливу ТОВ «Сумитеплоенерго», виявилося, що рівень техногенного навантаження на грунтовий покрив тут значно вищий. Грунти в безпосередній близькості від золошлаконакопичувача цього підприємства забруднені такими важкими металами: мідь, цинк, свинець, нікель, хром. Установлено, що грунти зони впливу основного корпусу характеризуються такою асоціацією важких металів: хром, свинець, мідь, нікель, ванадій. Грунти поблизу золошлаконакопичувача характеризуються високим (небезпечним) рівнем забруднення (СПЗ - 36). Грунти зони впливу основного корпусу - середнім (помірно небезпечним) (СПЗ - 16) (рис. 1).

Валові вмісти важких металів у досліджуваних грунтах, мг / кг

Таблиияя 1

\begin{tabular}{|c|c|c|c|c|}
\hline Eлемент & $\begin{array}{c}\text { Центральна частина } \\
\text { м. Суми } \\
(\mathrm{n}=50)\end{array}$ & $\begin{array}{c}\text { Територія зони впливу } \\
\text { основного корпусу } \\
\text { ТОВ «Сумитеплоенерго» } \\
(\mathrm{n}=35)\end{array}$ & $\begin{array}{c}\text { Територія зони впливу } \\
\text { золошлаковідвалу } \\
\text { ТОВ «Сумитеплоенерго» } \\
(\mathrm{n}=35)\end{array}$ & $\begin{array}{c}\text { Фонове значення } \\
(\mathrm{n}=40)\end{array}$ \\
\hline $\mathrm{Mn}$ & $500-1000(667)$ & $400-800(640)$ & $400-500(450)$ & 400 \\
\hline $\mathrm{Ni}$ & $40-100(63)$ & $60-100(80)$ & $40-50(45)$ & 30 \\
\hline $\mathrm{Co}$ & $5-10(7)$ & $8-10(9)$ & $5-8(6)$ & 5 \\
\hline $\mathrm{V}$ & $60-200(107)$ & $100-150(120)$ & $60-80(75)$ & 50 \\
\hline $\mathrm{Cr}$ & $50-300(143)$ & $100-500(330)$ & $50-80(68)$ & 3 \\
\hline $\mathrm{Mo}$ & $4-5(4)$ & $3-5(4)$ & $2-4(3)$ & 30 \\
\hline $\mathrm{Cu}$ & $50-100(67)$ & $60-100(84)$ & $30-50(38)$ & 20 \\
\hline $\mathrm{Pb}$ & $40-80(67)$ & $60-100(72)$ & $100-500(250)$ & 60 \\
\hline $\mathrm{Zn}$ & $50-68(62)$ & $60-80(72)$ & $3-4(3)$ & 4 \\
\hline $\mathrm{Sn}$ & $3-8(5)$ & $5-8(6)$ & & 50 \\
\hline
\end{tabular}

Примітка. Наведено граничні значення, у дужках - середнє значення, $\mathrm{n}$ - кількість проб. 


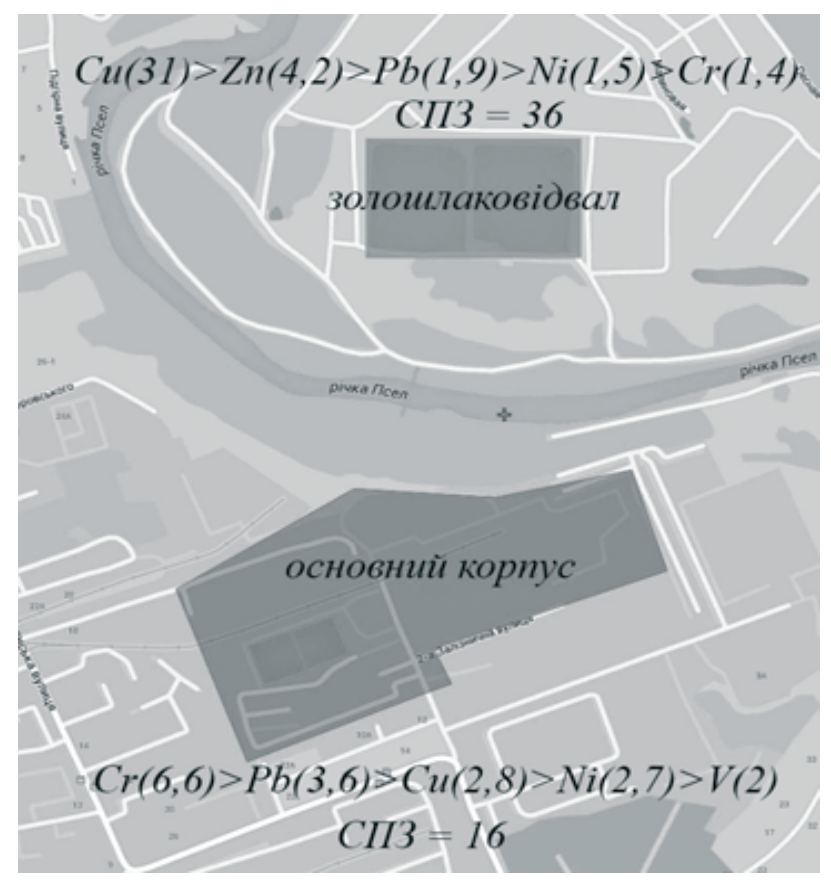

Рис. 1. Асоціації важких металів у грунтах зони впливу ТОВ «Сумитеплоенерго» та сумарні показники забруднення. У дужках наведено середні значення коефіцієнтів концентрації

Особлива увага була приділена вивченню біогеоценозів території досліджень. Експериментальні дослідження міграції важких металів проведено на найбільш поширеному представнику трав'янистої рослинності - пирії повзучому (Elytrigia repens (L.) Nevski). 3'ясувалося, що на техногенно забруднених ділянках (територія ТОВ «Сумитеплоенерго») вмісти важких металів у золі рослин удвічі-втричі більші порівняно із фоновою ділянкою (рис. 2).

Сучасний стан поверхневих водойм м. Суми характеризується антропогенним тиском суб'єктів господарювання, скидами недостатньо очищених стоків, які щорічно надходять до них. Також причинами незадовільного стану річок $\epsilon$ надходження неочищених зливових (талих) вод. Основні причини скиду забруднювальних вод такі: неефективна робота існуючих каналізаційних очисних споруд та їх недостатня кількість. Також не сприяють поліпшенню екологічного стану водних об'єктів існуючі технологічні схеми водоочисних споруд, застаріла технологія очищення стічних вод, значна зношеність існуючих водопровідних і каналізаційних мереж. Річка Псел приходить на територію Сумщини з Курської області Росії, iï басейн складає 23,4 \% території області. Основні забруднювачі р. Псел розташовані в межах м. Суми (“Dopovid' pro stan”, 2013).

Проведено порівняння даних середнього хімічного складу поверхневих вод р. Псел у районі ТОВ «Сумитеплоенерго» і на фоновій ділянці (рис. 3). Дослідження показали, що за макроскладом поверхневі води належать до гідрокарбонатно-кальцієвого типу. Слід зазначити, що в поверхневих водах зони впливу цього підприємства значно підвищується вміст таких важких металів відносно фонових значень: $\mathrm{Cu}, \mathrm{Zn}, \mathrm{Mn}, \mathrm{Ni}, \mathrm{Cr}, \mathrm{V}$. Це свідчить про техногенне забруднення поверхневих вод р. Псел у зоні впливу ТОВ «Сумитеплоенерго».

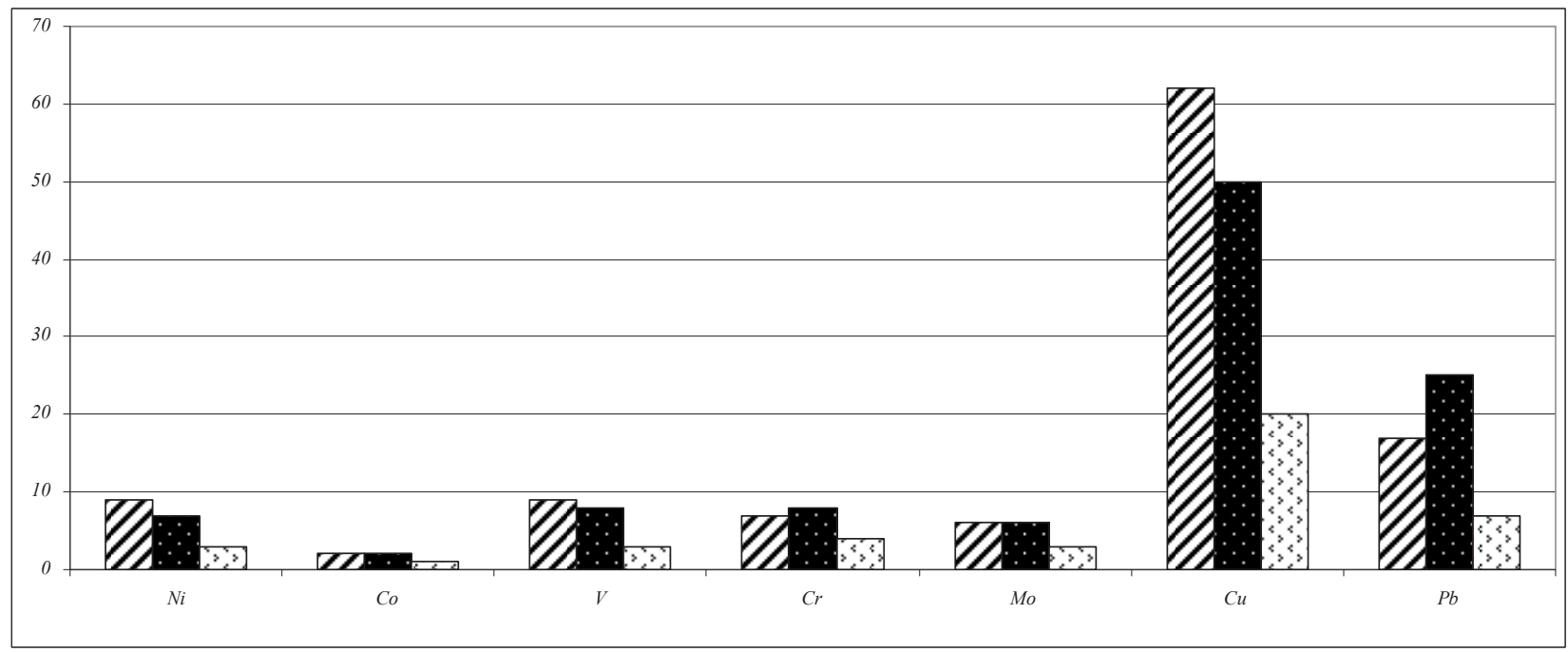

Рис. 2. Вміст важких металів у золі трав'янистої рослини пирій повзучий (Elytrigia repens (L.) Nevski), мг/кг. П - ділянка основного корпусу, $\mathbf{Z}$ - ділянка золошлаковідвалу ТОВ «Сумитеплоенерго», - фонова ділянка 


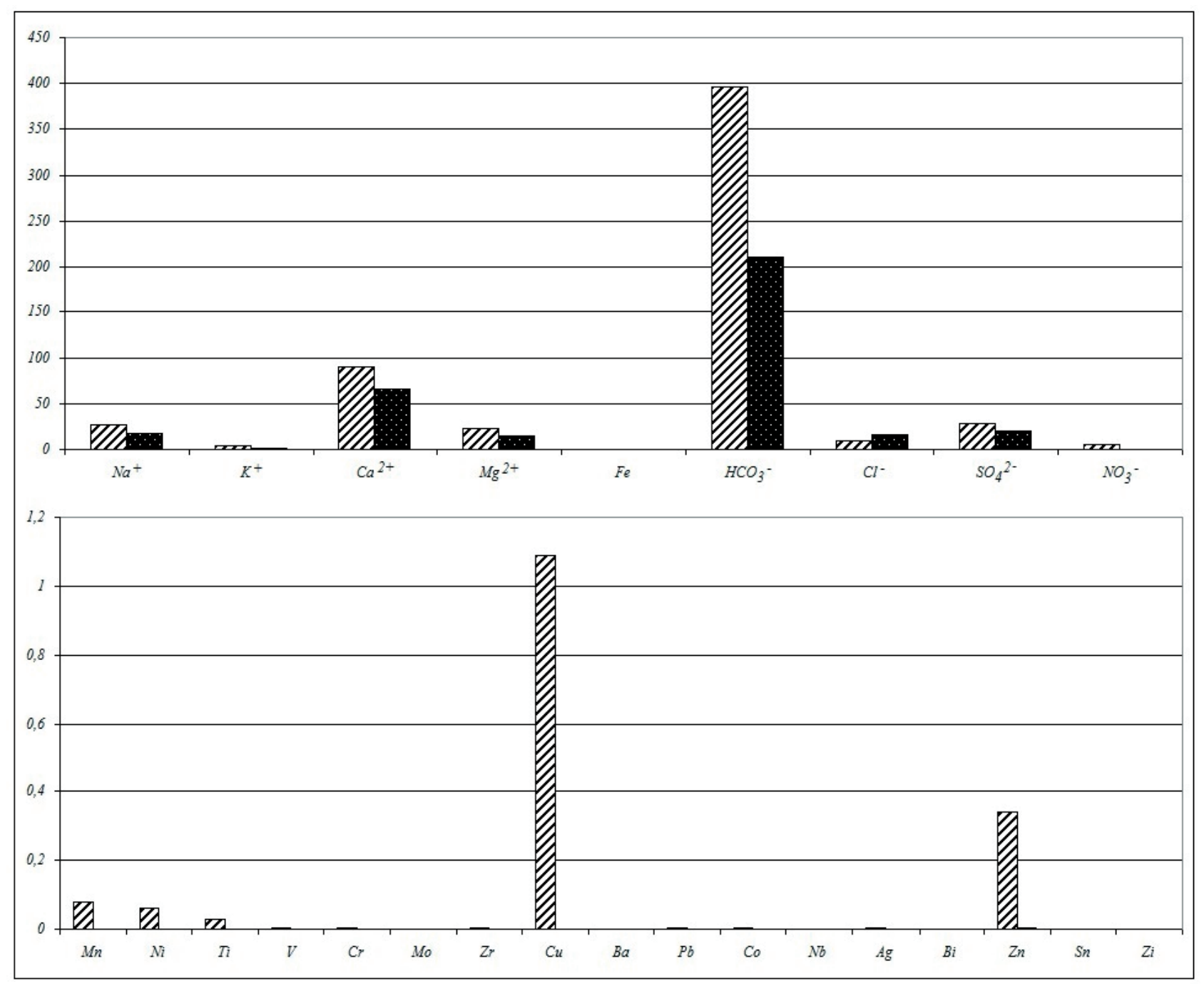

Рис. 3. Хімічний склад поверхневих вод р. Псел у зоні впливу ТОВ «Сумитеплоенерго» та на фоновій

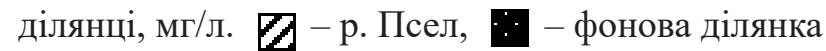

Зола кам’яного вугілля містить цілий ряд важких металів, які під час контакту золошлакової суміші $з$ атмосферними опадами здатні вилуговуватися, переходити у розчинні форми і потрапляти до грунтових вод шляхом інфільтрації. В аніонному складі досліджених підземних вод домінують сульфати і хлориди, а в катіонному - кальцій та натрій. Мінералізація - 900-1 200 мг/дм³ ; рН 7,3-7,5. Відмічено значні відмінності у макро- та мікрокомпонентному складі грунтових вод дослідженої ділянки від фонових. Показано, що за зміною співвідношення макро- та мікроелементів відбувся процес метаморфізації перших від поверхні водоносних горизонтів (рис. 4).

Також проводилися дослідження відходів виробництва ТОВ «Сумитеплоенерго» (табл. 2). Зола і шлак тут характеризуються значною концентрацією багатьох хімічних елементів, особли- во високі значення характерні для $\mathrm{V}, \mathrm{Cr}, \mathrm{Cu}, \mathrm{Pb} \mathrm{i}$ $\mathrm{Zn}$. Як показали дослідження, підвищені концентрації цих елементів характерні для грунтів і природних вод техногенно забруднених територій у зоні впливу згаданого підприємства.

\section{Середній вміст важких металів}

Таблиия 2

\section{у шлаках та золі, мг/кг}

\begin{tabular}{|c|c|c|c|c|c|c|c|c|c|c|c|}
\hline $\begin{array}{c}\text { № } \\
\text { 3/п }\end{array}$ & $\begin{array}{c}\text { Тип } \\
\text { зразка }\end{array}$ & $\mathrm{Mn}$ & $\mathrm{Ni}$ & $\mathrm{Co}$ & $\mathrm{V}$ & $\mathrm{Cr}$ & $\mathrm{Mo}$ & $\mathrm{Cu}$ & $\mathrm{Pb}$ & $\mathrm{Zn}$ & $\mathrm{Sn}$ \\
\hline 1 & шлаки & 1000 & 200 & 40 & 500 & 400 & 4 & 300 & 200 & 80 & 8 \\
\hline 2 & зола & 1000 & 200 & 20 & 400 & 350 & 2 & 200 & 300 & 300 & 8 \\
\hline
\end{tabular}

Висновки. В результаті вивчення ступеня забруднення грунтового покриву, рослинності та природних вод м. Суми важкими металами можна зробити загальний висновок про техногенне забруднення території. За середнім значенням сумарного 


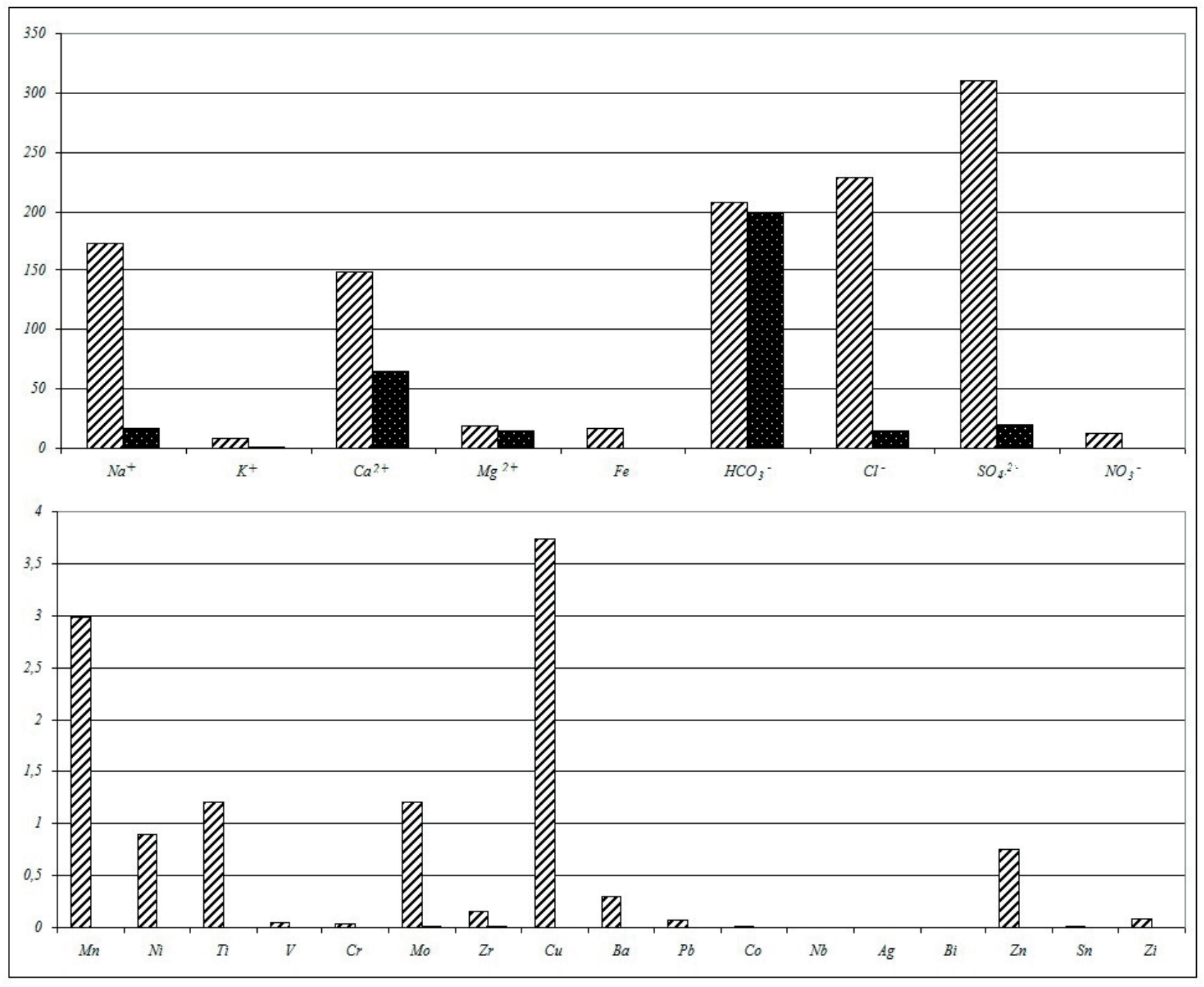

Рис. 4. Хімічний склад підземних вод зі свердловини 1 (водоносний горизонт - aQIVh) у зоні впливу золошлаковідвалу ТОВ «Сумитеплоенерго» та на фоновій ділянці, мг/л. $\square-$ свердловина $1, ?-$ фонова ділянка

показника встановлено, що рівень забруднення грунтів центральної частини міста нижчий середнього. Грунти зони впливу основного корпусу ТОВ «Сумитеплоенерго» характеризуються середнім (помірно небезпечним), а грунти поблизу золошлаконакопичувача - високим (небезпечним) рівнем забруднення. Встановлено техногенні геохімічні асоціації важких металів, досліджено основні джерела забруднення, що спричинюють накопичення токсикантів у компонентах міського середовища.

Багаторічна діяльність ТОВ «Сумитеплоенерго» викликала зміни природного співвідношення розподілу важких металів у всіх досліджених об'єктах довкілля. На техногенно забруднених ділянках (територія підприємства) вмісти важких металів у золі пирію повзучого (Elytrigia repens (L.) Nevski) вдвічі-втричі більші порівнянно із фоновою ділянкою. В поверхневих водах р. Псел зони впливу цього закладу значно підвищується вміст таких важких металів відносно фонових значень: $\mathrm{Cu}, \mathrm{Zn}, \mathrm{Mn}, \mathrm{Ni}, \mathrm{Cr}, \mathrm{V}$. Показано, що відбувся процес метаморфізації перших від поверхні водоносних горизонтів у зоні впливу золошлаконакопичувача ТОВ «Сумитеплоенерго».

Отримані результати можуть служити основою для складання багаторічного перспективного плану охорони навколишнього середовища міської агломерації і геохімічного моніторингу.

\section{Бібліографічні посилання}

Dopovid' pro stan navkolyshn'ogo pryrodnogo seredovyshha u Sums'kij oblasti u 2012 roci. (2013). [Report on the state of the environment in the Sumy region in 2012]. Sumy. Sumy Regional State Administration. Department of Ecol- 
ogy, Energy Sector and Natural Resources. (in Ukrainian).

Flight, DMA, Scheib, AJ. (2011). Soil geochemical baselines in UK urban centers: the G-BASE project. In: Johnson, CC, Demetriades, A, Locutura, J, Ottesen, RT, Mapping the Chemical Environment of Urban Areas. John Wiley \& Song, Chichester, 186-206.

Kabata-Pendias, A., Pendias, H. (2001). Trace elements in Soils and Plants. CRC Press.

Karmazynenko, S.P., Kurajeva, I.V., Samchuk, A.I., Vojtjuk, Ju.Ju., Manichev, V.J. (2014). Vazhki metaly u komponentah navkolyshn'ogo seredovyshha m. Mariupol' (ekologo-geohimichni aspekty) [Heavy metals in the components of the environment. Mariupol (ecological and geochemical aspects)]. Interservis, Kyiv (in Ukrainian).

Kuimova, N.G., Sergeeva, A.G., Shumilova, L.P., Pavlova, L.M., Borisova, I.G. (2012). Jekologo-geohimicheskaja ocenka ajerotehnogennogo zagrjaznenija urbanizirovannoj territorii po sostojaniju snezhnogo pokrova [Ecological-geochemical assessment of environmental contamination on the urban area of snow cover]. Geojekologija, inzhenernaja geologija, gidrogeologija, geokriologija. 5, 422-435 (in Russian).
Ponomarenko, O.M., Samchuk, A.I., Krasjuk, O.P., Makarenko, T.I., Antonenko, O.G. (2008). Analitychni shemy probo pidgotovky girs'kyh porid ta mineraliv i vyznachennja $\mathrm{v}$ nyh mikroelementiv metodom mas-spektrometrii' $\mathrm{z}$ indukcijno zv'jazanoju plazmoju (ICP-MS) [Analytical samples training schemes rocks and minerals and trace elements in their determination by mass spectrometry with induction coupled plasma (ICP-MS)]. Mineralogichnyj zhurnal. 30 (2), 97-103 (in Ukrainian).

Saet, Ju.E., Revich, B.A., Janin, E.P. (1990). Geohimija okruzhajushhej sredy [Environmental Geochemistry]. Nedra, Moscow (in Russian).

Samchuk, A.I., Ogar', T.V. (2008). Rozpodil mikroelementiv u g'runtah ta roslynnosti pryrodnyh i tehnogennyh landshaftiv [The distribution of trace elements in soils and vegetation of natural and man-made landscapes]. Mineralogichnyj zhurnal. 30 (1), 80-86 (in Ukrainian).

Wong, CI, Sharp, JM Jr, Hauwert, N, Landrum, J, White, KW (2012). Impact of urban development on physical and chemical hydrogeology. Elements 8: 429-434.

Надійшла до редколегіï 5.09.2016 